\title{
Sosialisasi Pencegahan Stunting pada Anak Balita di Kelurahan Cawang Jakarta Timur
}

\author{
Sri Melfa Damanik ${ }^{1}$, Erita Sitorus ${ }^{2}$, I Made Mertajaya ${ }^{3}$ \\ 1,2,3 Universitas Kristen Indonesia, Jakarta, Indonesia
}

melfadamanik20@gmail.com; eritasitorus1@gmail.com; immerta@yahoo.com

\begin{abstract}
ABSTRAK
Stunting merupakan salah satu kondisi gagal tumbuh pada anak dimana tinggi badan anak <-2SD menurut tabel Z-score WHO. Ada beberapa hal yang menjadi penyebab utama masalah stunting pada anak, salah satunya yaitu ketidakoptimalan praktik pemberian makan anak. Tujuan Pelaksanaan Pengabdian kepada Masyarakat (PKM) ini yaitu untuk meningkatkan pengetahuan dan ketrampilan ibu tentang pencegahan stunting melalui edukasi praktik pemberian makan yang tepat berdasarkan rekomendasi WHO. Sebanyak 40 ibu yang memiliki anak Balita ikut dalam kegiatan PKM. Metode pelaksanaan PKM yaitu sosialisasi yang dikombinasikan dengan survei secara kuantitatif tentang pelaksanaan praktek pemberian yang dilakukan oleh ibu berdasarkan indikator praktik pemberian makan menurut rekomendasi WHO. Hasil PKM menunjukkan terdapat perbedaan yang signifikan antara nilai pre dan posttest peserta setelah diberikan sosialisasi di Kelurahan Cawang, Jakarta timur $(P<0,001)$ dan $90 \%$ ibu mengalami peningkatan pengetahuan. Pemahaman ibu yang memiliki anak Balita tentang pencegahan stunting melalui pemberian makanan yang tepat dapat menurunkan risiko masalah stunting di Indonesia.
\end{abstract}

Kata Kunci : Stunting; Anak Balita; Praktik pemberian makan

\begin{abstract}
Stunting is a condition of failing to thrive in children where child's height is $<-2$ SD according to WHO Z-score table. There are several major causes of stunting problem in children, one of which is inadequate practice of feeding for children. . The purpose of this study is to increase the knowledge and skills of mothers about stunting prevention through education on proper feeding practices based on WHO recommendations. 40 mothers who have infant and young children participate in this study. The method of this study is socialization combine with a quantitative survey about indicators of feeding practice according to WHO recommendation. The result showed that there was a significant difference between the pre and post test scores of the participants after being given socialization in Cawang Village, East Jakarta $(P<0,001)$ and $90 \%$ of mothers experienced an increase in knowledge. The understanding of mothers who have infant and young children about stunting prevention through proper feeding can reduce the risk of stunting problems in Indonesia
\end{abstract}

Keywords : Stunting; infant and young children; feeding practices 


\section{PENDAHULUAN}

Stunting adalah salah satu kondisi gagal tumbuh pada anak karena masalah gizi kronis yang ditandai dengan panjang atau tinggi anak tidak sesuai dengan usia atau $<-2$ SD berdasarkan tabel Z-Score WHO. Anak Balita yang mengalami stunting menunjukkan adanya masalah gizi kronis yang perlu diatasi dan dicegah melalui praktik pemberian makanan yang benar dan sesuai standar. WHO menyatakan bahwa praktik pemberian makanan yang baik merupakan salah satu indikator untuk menilai kebutuhan nutrisi anak apakah sudah terpenuhi secara optimal atau tidak (WHO, 2018). Praktik pemberian makan yang sesuai standar merupakan indikator yang perlu dipenuhi dalam memberikan kebutuhan nutrisi pada Balita sesuai tumbuh kembang.

Balita yang mengalami stunting merepresentasikan adanya masalah gizi kronis yang perlu diperbaiki melalui upaya pencegahan dan pengurangan gangguan secara langsung dan tidak langsung. Penanggulangan masalah stunting sangat efektif dilakukan pada 1000 hari kehidupan. Periode 1000 hari kehidupan meliputi 270 hari selama kehamilan, dan 730 hari pertama setelah bayi yang dilahirkan telah dibuktikan secara ilmiah merupakan periode kritis yang menentukan kualitas kehidupan (Kemenkes, 2016).
Dampak buruk yang dapat ditimbulkan oleh masalah gizi pada periode tersebut dalam jangka pendek adalah terganggunya perkembangan otak, kecerdasan, gangguan pertumbuhan fisik dan gangguan metabolisme dalam tubuh. Sedangkan dampak jangka panjang yaitu menurunnya kemampuan kognitif dan prestasi belajar, menurunnya kekebalan tubuh sehingga mudah sakit, resiko untuk munculnya penyakit Diabetes, kegemukan, penyakit jantung dan pembuluh darah, kanker, stroke, disabilitas pada usia tua serta kualitas kerja yang tidak kompetitif (WHO, 2018; Kemenkes RI, 2017).

Ada banyak faktor yang menjadi penyebab tingginya angka kejadian stunting pada Balita yaitu faktor dari dalam diri anak seperti usia, jenis kelamin, berat badan lahir dan faktor dari luar diri anak seperti sosial ekonomi dan praktik pemberian makan oleh ibu. Praktik pemberian makan pada anak memiliki kontribusi terhadap kejadian stunting misalnya ketidakoptimalan pemberian ASI Eksklusif (khususnya pemberian ASI non eksklusif) dan pemberian makanan pendamping yang terbatas dalam hal jumlah, kualitas dan variasi jenisnya (WHO, 2018).

Uwiringiyama, Ocke, Amer, dan Veldkamp (2018) dan Fekadu, Mesfin, Haile, dan Stoecker (2015) menjelaskan bahwa pemberian ASI Eksklusif selama 6 bulan memiliki pengaruh yang signifikan mengurangi peluang stunting pada anak. 
Udoh dan Amodu (2016) juga mejelaskan bahwa bayi yang tidak menerima keragaman diet minimum dan frekuensi makan minimum secara signifikan lebih mungkin mengalami stunting dibandingkan anak yang mendapatkan diet yang sesuai.

Jakarta merupakan salah satu provinsi yang memiliki jumlah Balita yang mengalami stunting cukup tinggi yaitu sebanyak $17,7 \quad \%$. Pemahaman masyarakat tentang masalah stunting pada anak masih cukup rendah. Salah satu cara yang dapat dilakukan untuk meningkatkan pemahaman dan kepedulian terhadap masalah stunting pada anak adalah dengan pemberian edukasi kesehatan. Edukasi sangat penting dilakukan untuk meningkatkan pemahaman ibu tentang pencegahan stunting dengan menerapkan praktik pemberian makan yang benar sesuai rekomendasi WHO.

\section{METODE}

Kegiatan pengabdian kepada masyarakat ini dilakukan dengan metode ceramah, diskusi dan Tanya jawab. Sasaran pengabdian ini adalah Ibu yang memiliki anak Balita. Peserta yang terlibat dalam kegiatan penyuluhan ada sebanyak 40 ibu. Semua peserta yang hadir berasal dari perwakilan masing-masing RT yang ada di Kelurahan Cawang, Jakarta Timur.
Kegiatan pengabdian ini dilakukan bekerja sama dengan Puskesmas Kelurahan Cawang pada tanggal 3 September 2019 di Puskesmas kelurahan Cawang, Jakarta Timur. Media yang digunakan adalah media power point, leaflet. Adapun metode sosialisasi yang digunakan adalah active and participatory learning. Dalam pelaksanaan pengabdian sebelum dan setelah penyampaian materi dilakukan pengisian kuesioner tentangkarakteristik peserta, serta pengetahuan tentang indikator praktik pemnerian makan yang benar.

Materi dalam kegiatan pengabdian kepada masyarakat ini sesuai dengan kebutuhan dan maslah yang dialami oleh Ibu. Materi penyuluhan yang disampaikan meliputi : pengertian stunting, angka kejadian stunting di dunia dan di Indonesia, tanda dan gejala stunting pada anak, dampak stunting serta pencegahan stunting pada anak dengan memperhatikan praktik pemberian makan berdasarkan rekomendasi oleh WHO diantaranya yaitu melakukan Inisiasi Menyusu Dini (IMD) minimal 1 jam setelah bayi lahir, memberikan ASI Eksklusif selama 6 bulan, memberikan ASI lanjutan sampai usia 2 tahun, memperhatikan frekuensi pemberian makan, memperhatikan keragaman makanan dan porsi makanan,serta memberikan maknan yang kaya akan zat besi. 
HASIL DAN PEMBAHASAN

Kegiatan penyuluhan kesehatan dilakukan di Ruang Aula Puskesmas Kelurahan Cawang. Proses kegiatan berjalan dengan lancar dan tidak ada kendala apapun yang ditemukan. Para ibu yang hadir dengan aktif mendengarkan materi yang disampaikan oleh narasumber dan aktif bertanya.
Karakteristik ibu dalam kegiatan pengabdian ini dikategorikan berdasarkan usia, pendidikan dan pekerjaan. Pembagian usia sesuai dengan pembagian usia menurut WHO (2015) yaitu dewasa (17-45 tahun). Persentase karakteristik responden disajikan dalam tabel 1.

Tabel 1. Karakteristik ibu di Kelurahan Cawang, Jakarta Timur

\begin{tabular}{lll}
\hline Kharakteristik & Jumlah Responden ( Orang) & $\%$ \\
\hline Usia & & 100 \\
Dewasa ( 17-45) & 40 & 95 \\
Pekerjaan & & 2,5 \\
lbu Rumah Tangga & 38 & 2,5 \\
Karyawan & 1 & \\
Swasta & 1 & 5 \\
Pendidikan & & 25 \\
SD & 2 & 55 \\
SMP & 10 & 2,5 \\
SMA & 22 & 12,5 \\
D III & 1 & \\
Sarjana (S1) & 5 & .
\end{tabular}

Berdasarkan latar belakang pendidikan,

Berdasarkan data Tabel 1 menunjukkan bahwa sosialisasi tersebut diikuti oleh ibu yang memiliki anak Balita dengan semua peserta berada pada kategori usia dewasa (17-45 tahun). Menurut Koder (2006) usia produktif memiliki tingkat pengetahuan yang lebih tinggi dibandingkan dengan usia lanjut. Hal ini disebabkan karena usia produktif mengikuti perkembangan pengetahuan, memiliki kemampuan menangkap informasi yang lebih baik karena fungsi organ dan panca indranya masih berfungsi dengan baik.

Ditinjau dari segi pekerjaan,sebagian besar peserta adalah ibu rumah tangga (95\%), Karyawan (5\%) dan pegawai swasta (5\%). pserta yang hadir sebagian besar dengan pendidikan terakhir SMA (55\%), SMP (25\%), Sarjana S1 (12,5\%), SD (5\%) dan Diploma (2,5 \%). Tingkat pendidikan akan mempengaruhi sikap seseorang dalam mengatasi suatu masalah. Seseorang yang berpendidikan ketika menghadapi suatu masalah akan berusaha memecahkan masalah tersebut sebaik mungkin (Petter \& Potter, 2005). Melalui proses pendidikan, seseorang akan memperoleh pengetahuan, pemahaman dan wawasan yang lebih baik termasuk pengetahuan tentang bagaimana cara mengatasi anak untuk terhindar dari masalah stunting yang menjadi sebuah issue yang sering diperbincangkan pada 
masa ini. Notoatmodjo (2007) menjelaskan bahwa status pekerjaan seseorang akan mempengaruhi sikap dan pengetahuan atas informasi yang telah diterima.

\section{Gambaran Tingkat Pengetahuan}

Kegiatan pretest dilakukan sebelum pemberian materi edukasi melalui penyuluhan kepada para ibu hamil dan ibu yang memiliki anak Balita di Kelurahan Cawang, Jakarta Timur. Tujuan dilakukan pretest adalah untuk mengetahui tingkat pengetahuan peserta yang hadir tentang pencegahan stunting pada anak. Terdapat 10 butir pertanyaan pretest yang berupa soal pilihan ganfa (multiple choice).
Kegiatan posttest dilakukan setelah pemberian materi oleh narasumber. Tujuan posttest dilakukan adalah untuk mengetahui adanya perubahan tingkat pengetahuan peserta setelah materi disampaikan. Sebelum post-test dilakukan terdapat sesi diskusi dimana setiap peserta memiliki kesempatan yang sama untuk bertanya kepada narasumber pada kegiatan penyuluhan tersebut. Adapun soal posttest sebanyak 10 butir pertanyaan yang berupa soal pilihan ganda dan jenis soalnya sama dengan soal pretest di awal. Adanya peningkatan nilai pretest-posttest setelah pemberian materi dapat dilihat pada tabel 2 .

Tabel 2. Hasil uji beda nilai Pretest dan postetst peserta sosialisasi

\begin{tabular}{lll}
\hline Evaluasi Penilaian & Jumlah & Sig. $(\mathrm{p})$ \\
\hline Peningkatan Nilai Pretest-Post test & 36 & $\mathrm{P}<0,05$ \\
tetap & 4 &
\end{tabular}

sosialisasi setelah diberikan sosialisasi

Tabel 2 menunjukkan bahwa adanya peningkatan nilai pretest-posttest sebanyak 36 orang peserta sosialisasi yang hadir yaitu ibu yang memiliki anak Balita di Kelurahan Cawang, Jakarta Timur. 4 orang peserta memiliki nilai pretest dan post test tetap. Hasil uji beda antara nilai pre dan posttest menunjukkan bahwa nilai signifikansi $p<0,05$. Hasil ini menunjukkan bahwa terdapat perbedaan yang signifikan antara nilai pre dan posttest peserta

\section{Sosialisasi Pencegahan Masalah stunting pada anak}

Kegiatan sosialisasi tentang pencegahan stunting pada anak sejak dini di Kelurahan Cawang Jakarta Timur menunjukkan bahwa tentang pencegahan masalah stunting pada anak di kelurahan cawang, Jakarta timur. Tabel 2 juga menunjukkan bahwa ada sebanyak 4 peserta yang memiliki nilai pretets dan postest yang tetap. Salah satu penyebab tidak adanya perbedaan nilai pretest dan post test dipengaruhi oleh persepsi individu. Jika persepsi antara peserta dan pemberi edukasi berbeda maka informasi yang disampaikan tidak akan maksimal.

adanya peningkatan pengetahuan peserta sosialisasi berdasarkan hasil survei yang dilakukan. Sebelum dilakukan sosialisasi masih banyak masyarakat yang tidak memahami istilah "stunting" dan kurangnya 
informasi tentang bagaimana praktik pemberian makan yang benar sesuai dengan yang direkomendasikan oleh WHO. Namun diperoleh data bahwa setelah sosialisasi diberikan peserta sosialisasi sudah mengetahui tentang pengertian stunting, cara menilai stunting pada anak, mengenal indikator praktik pemberian makan yang benar sesusi rekomendasi oleh WHO meliputi Inisiasi Menyusu Dini (IMD 1 jam setelah bayi lahir, ASI eksklusif selama 6 bulan, Pemberian ASI lanjutan sampai usia 2 tahun, Frekuensi pemberian makanan anak sesuai usia anak, memperhatikan keragaman makanan (minimal 4 jenis makanan yang berbeda yang terdiri dari karbohidrat, lauk, sayur, buah dan susu), dan memberikan makanan yang mengandung zat besi yang tinggi.

Berdasarkan data yang diperoleh masih ditemukan banyak ibu yang belum melakukan Inisiasi Menyusu Dini ( IMD) pada bayinya selama 1 jam setelah lahir. Pemberian IMD selama 1 jam setelah lahir memberikan banyak manfaat bagi bayi selain bayi mendapatkan nutrisi yang sangat baik juga bayi dapat kontak dengan ibunya secara langsung (WHO, 2010). Muchina dan Waithaka (2010) menjelaskan bahwa insiden stunting pada anak memiliki hubungan yang signifikan dengan waktu dilakukannya IMD dimana ditemukan bahwa anak yang diberikan ASI setelah 1 jam dari waktu bayi lahir berpeluang 2 kali lebih tinggi mengalami stunting dibandingkan dengan anak yang mendapatkan ASI dalam 1 jam pertama bayi lahir.

Lama pemberian ASI berpengaruh terhadap risiko kejadian stunting pada anak. Kuchen et al. (2015) menjelaskan bahwa Terdapat hubungan antara ASI Eksklusif dan LAZ (Length-for-age Z-score) dimana bayi yang mendapat ASI Eksklusif memiliki mean LAZ yang lebih tinggi daripada bayi tidak disusui secara eksklusif. Hal yang sama juga dibuktikan oleh Perkins, Jayatissa, dan Subramanian (2018), dalam penelitiannya disebutkan bahwa proporsi anak yang mengalami stunting dan tidak diberikan asi Eksklusif jauh lebih besar dibanding dengan prevalensi anak stunting yang diberikan ASI Eksklusif.

Selain Pemberian ASI, praktik pemberian makan yang tidak sesuai anjuran dapat menjadi penyebab anak mengalami stunting. Di Masyarakat masih banyak ibu belum memberikan makan dengan frekuensi yang sesuai usia anak dan keragaman makanan yang masih belum optimal. Frekuensi pemberian makan pada anak memiliki pengaruh yang positif terhadap status nutrisi pada anak. Beberapa penelitian membuktikan bahwa minimal frekuensi pemberian makan, memberi peluang yang lebih besar terhadap masalah stunting pada anak. Udoh dan Amodu (2016) dalam penelitiannya membuktikan bahwa bayi yang tidak menerima keragaman diet minimum dan frekuensi diet minimum secara signifikan 
memiliki peluang yang lebih besar untuk mengalami stunting. Ibu yang memberi makanan dengan memperhatikan keragaman makanan atau minimal 4 dari kelompok makanan yang berbeda sesuai rekomendasi WHO memiliki peluang $83 \%$ lebih rendah kemungkinan mengalami stunting dibandingkan dengan anak yang mendapatkan keragaman diet amakanan yang tidak adekuat (Ahmad, Khalique, Khalil, \& Maroof, 2018). Oleh karena itu jenis makanan yang beragam dan memperhatikan frekuensi makan yang sesuai dapat berkontribusi terhadap risiko stunting pada anak

Pengetahuan ibu tentang praktik pemberian makan yang benar merupakan sebuah langkah awal untuk dapat memberikan nutrisi yang adekuat dan bergizi terhadap anaknya, sehingga dengan asupan gizi yang baik oleh ibu diharapkan kejadian stunting pada anak dapat diminimalisir. Dengan adanya sosialisasi tentang pencegahan masalah stunting pada anak secara rutin dilakukan di masyarakat diharapkan ibu dapat mengubah perilaku ibu dan memotivasi ibu untuk berkontribusi secara aktif dalam mendukung pertumbuhan dan perkembangan anak di Indonesia. Nutrisi yang adekuat selama 1000 hari pertama kehidupan merupakan salah satu faktor penting yang perlu diupayakan oleh ibu untuk mencegah masalah stunting pada anak dan dapat meningkatkan indeks pembangunan manusia.

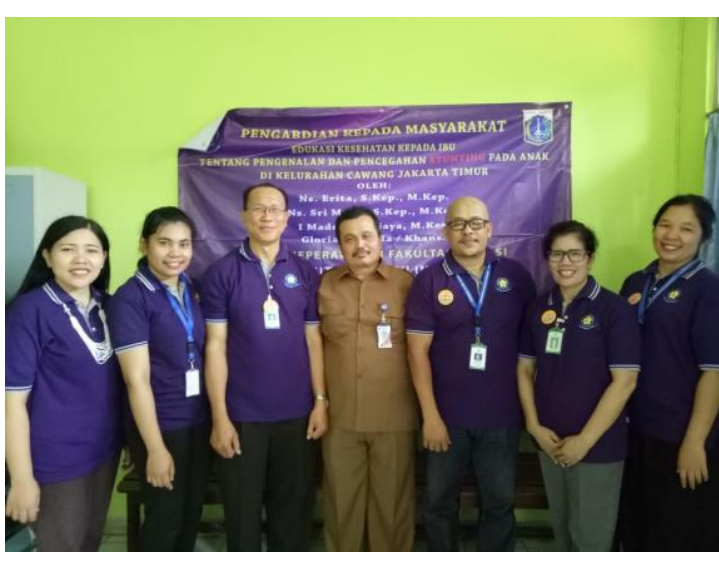

Gambar 1. Dosen Prodi DIII Keperawatan Fakultas Vokasi UKI bekerjasama dengan Puskesmas Kelurahan Cawang, Jakarta Timur dalam melakukan Kegiatan Pengabdian kepada masyarakat Cawang.

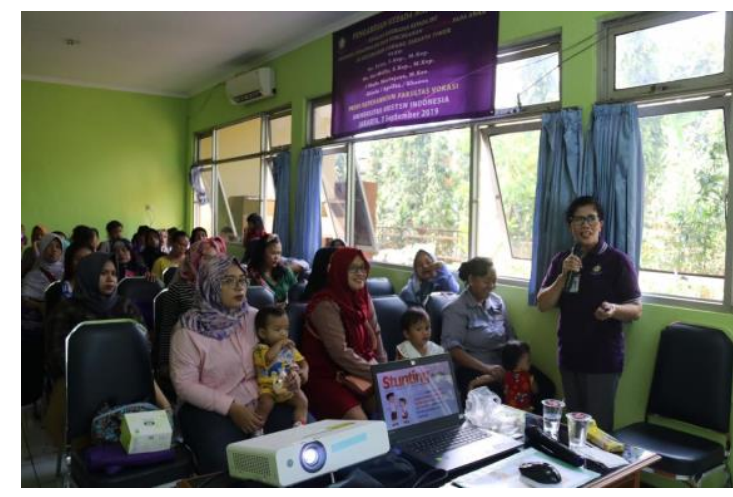

Gambar 2. Warga Cawang tampak antusias menghadiri kegiatan PkM yang dilakukan oleh Dosen dan Mahasiswa Prodi DIII Keperawatan Fakultas Vokasi UKI

\section{SIMPULAN}

Pemberian sosialisasi tentang masalah stunting serta pencegahan stunting pada ibu yang memiliki anak Balita merupakan strategi penting yang perlu dilakukan untuk meningkatkan pengetahuan masyarakat tentang dampak dan bahaya stunting pada anak. Pemberian edukasi diketahui dapat meningkatkan pengetahuan baru bagi ibu yang memiliki anak Balita di kelurahan Cawang, Jakarta Timur. Pemberian edukasi yang dilakukan secara rutin di masyarakat dapat menjadi salah satu solusi yang tepat untuk meningkatkan derajat kesehatan 
masyarakat dan mengurangi angka kejadian stunting pada anak di Indonesia.

\section{UCAPAN TERIMA KASIH}

Ucapan terima kasih kami sampaikan kepada :Pimpinan Universitas Kristen Indonesia yang telah memfasilitasi dana demi terselenggaranya kegiatan pengabdian kepada masyarakat ini, Pimpinan Lembaga penelitian dan Pengabdian Masyarakat (LPPM) Universitas Kristen Indonesia yang telah membantu dalam proses mulai dari penyusunan proposal hingga penyusunan laporan PkM, Dekan Fakultas Vokasi dan Kaprodi DIII Keperawatan UKI dengan baik serta Kepala Puskesmas Kelurahan Cawang yang sudah memberikan izin melaksanakan PkM di Kelurahan Cawang, Jakarta Timur

\section{REFERENSI}

Ahmad, I., Khalique, N., Khalil, S., \& Maroof, M. (2018). Dietary diversity and stunting among infants and young children : A cross - sectional study in Aligarh. Indian Journal of Community Medicine, 43, 34-37. https://doi.org/10.4103/ijcm.IJCM.

Fekadu, Y., Mesfin, A., Haile, D., \& Stoecker, B.J. (2015). Factors associated with nutritional status of infants and young children in Somali Region, Ethiopia: A cross- sectional study. BMC Public Health, 15(846), $1-10$.

https://doi.org/10.1186/s12889-0152190-7.
Kementrian Kesehatan RI. (2017). Buku saku pemantauan status gizi 2017. Kementrian Kesehatan RI : Direktorat Jenderal Kesehatan Masyarakat.

Kementrian Kesehatan RI. (2016). Infodatin : Situasi balita pendek. Kementrian Kesehatan RI : Pusat Data Dan Informasi. Diakses pada http://www.depkes.go.id/resources/d ownload/pusdatin/infodatin/situasibal ita-pendek-2016.pdf. tanggal 15 September 2018.

Kuchenbecker, J., Jordan, I., Reinbott, A., Herrmann, J., Jeremias, T., Kennedy, G., Muehlhoff, E., Mtimuni, B., \& Krawinkel, M.B. (2015). Exclusive breastfeeding and its effect on growth of Malawian infants: Results from a cross-sectional study. Paediatrics and International Child Health, 35(1), 14-23, DOI: 10.1179/2046905514Y.0000000134.

Muchina, E., \& Waithaka, P. M. (2010). Nutritional status of children aged 0 24 months in Nairobi, Kenya. African Journal Of Food Agriculture Nutrition And Development, 10(4), 23582378.

Notoadmodjo, S. 2007. Pendidikan dan PerilakuKesehatan. Jakarta : Rineka Cipta.

Perkins, J.M., Jayatissa, R. \& Subramanian, S.V. (2018). Dietary diversity and anthropometric status and failure among infants and young children in Sri Lanka. Nutrition, 55(56), 76-83. 
https://doi.org/10.1016/j.nut.2018.03. 049.

Potter, P.A, Perry, A.G. 2005. Buku Ajar FundamentalKeperawatan : Konsep, Proses dan Praktek, Edisi4, Volume 2, Alih Bahasa : Renata Komalasari,dkk, Jakarta : EGC.

Udoh, E. E., \& Amodu, O. K. (2016). Complementary feeding practices among mothers and nutritional status of infants in Akpabuyo Area, Cross River State Nigeria. SpringerPlus, 5(2073), 1-19 https://doi.org/10.1186/s40064-0163751-7.

Uwiringiyama, V., Ocke, M.C., Amer, S., \& Veldkamp. (2018). Predictors of stunting with particular focus on complementary feeding practice: A cross-sectional study in the Northern Province of Rwanda. Nutrition, 1-30. https://doi.org/10.1016/j.nut.2018.07. 016.

World Health Organization (WHO). (2010). Indicators for Assessing Infant and Young Child Feeding Practices:Conclusions of a Consensus Meeting Held 6-8 November 2007 in Washington, D.C., USA, Part II: Measurement.World Health Organization: Geneva, Switzerland, $20 \mathrm{pp}$.

WHO (2018). WHO Global target 2025 : Stunting policy brief. Diunduh pada tangal 16 September 2018 jam 20.00 WIB dari http://www.who.int/nutrition/globaltarget-2025/en/. 